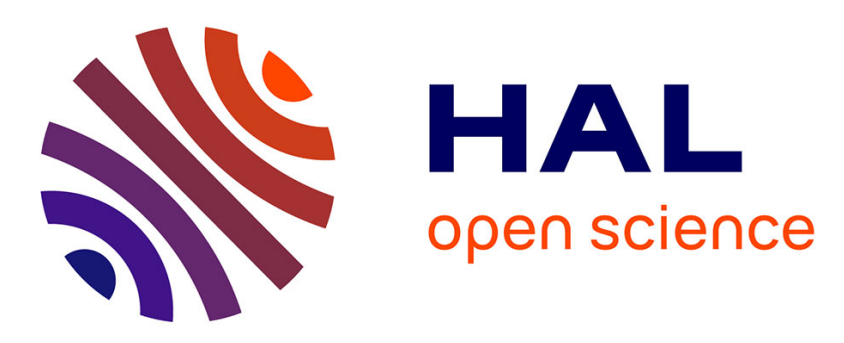

\title{
Distribution and contamination of trace metals in surface sediments of the East China Sea
}

\author{
Tien-Hsi Fang, Jou-Yun Li, Hui-Min Feng, Hung-Yu Chen
}

\section{To cite this version:}

Tien-Hsi Fang, Jou-Yun Li, Hui-Min Feng, Hung-Yu Chen. Distribution and contamination of trace metals in surface sediments of the East China Sea. Marine Environmental Research, 2009, 68 (4), pp.178. 10.1016/j.marenvres.2009.06.005 . hal-00563083

\section{HAL Id: hal-00563083 \\ https://hal.science/hal-00563083}

Submitted on 4 Feb 2011

HAL is a multi-disciplinary open access archive for the deposit and dissemination of scientific research documents, whether they are published or not. The documents may come from teaching and research institutions in France or abroad, or from public or private research centers.
L'archive ouverte pluridisciplinaire HAL, est destinée au dépôt et à la diffusion de documents scientifiques de niveau recherche, publiés ou non, émanant des établissements d'enseignement et de recherche français ou étrangers, des laboratoires publics ou privés. 


\section{Accepted Manuscript}

Distribution and contamination of trace metals in surface sediments of the East

China Sea

Tien-Hsi Fang, Jou-Yun Li, Hui-Min Feng, Hung-Yu Chen

PII:

S0141-1136(09)00068-3

DOI:

10.1016/j.marenvres.2009.06.005

Reference:

MERE 3345

To appear in:

Marine Environmental Research

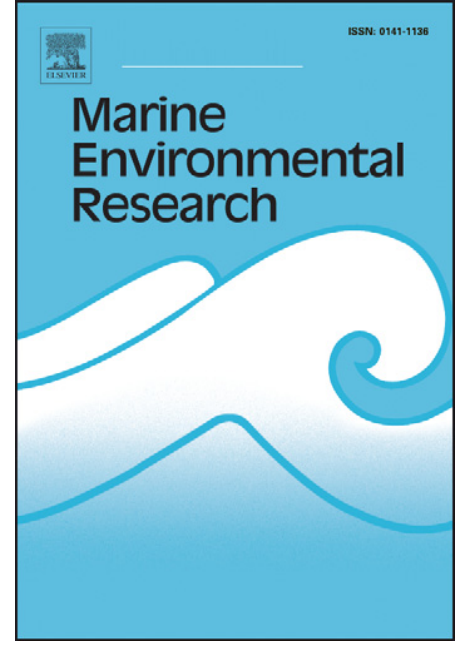

Received Date: $\quad 19$ November 2008

Revised Date: $\quad 20$ March 2009

Accepted Date: $\quad 2$ June 2009

Please cite this article as: Fang, T-H., Li, J-Y., Feng, H-M., Chen, H-Y., Distribution and contamination of trace metals in surface sediments of the East China Sea, Marine Environmental Research (2009), doi: 10.1016/ j.marenvres.2009.06.005

This is a PDF file of an unedited manuscript that has been accepted for publication. As a service to our customers we are providing this early version of the manuscript. The manuscript will undergo copyediting, typesetting, and review of the resulting proof before it is published in its final form. Please note that during the production process errors may be discovered which could affect the content, and all legal disclaimers that apply to the journal pertain. 


\title{
Distribution and contamination of trace metals in surface sediments of the East China Sea
}

\author{
Tien-Hsi Fang ${ }^{*}$, Jou-Yun Li, Hui-Min Feng, Hung-Yu Chen
}

Department of Marine Environmental Informatics, National Taiwan Ocean University, Keelung 202, Taiwan.

*Correspondence:

Dr. Tien - Hsi Fang

Department of Marine Environmental Informatics

National Taiwan Ocean University,

Keelung, 202, Taiwan.

Tel: 886-2-4622192 ext 6343

Fax: 886-2-4627674

E-mail: thfang@mail.ntou.edu.tw 


\section{ACCEPTED MANUSCRIPT}

2 The distributions, contamination status and annual sedimentation flux of trace

3 metals in surface sediments of the East China Sea (ECS) were studied. Higher

4 concentrations of the studied metals were generally found in the inner shelf and the

5 concentrations decreased seaward. The sequences of the enrichment factor (EF) of the

6 studied metals are $\mathrm{Cu}>\mathrm{Mn}>\mathrm{Ni} \cdot \mathrm{Zn}>\mathrm{Pb}>\mathrm{Fe}$. The values of EF suggest that the

7 metals contamination in the middle and outer shelves of the ECS is still minor. The

8 annual sedimentation fluxes of trace metals in the ECS were: Fe, $3.48 \times 10^{7} \mathrm{t} / \mathrm{y}$; Mn,

$99.07 \times 10^{5} \mathrm{t} / \mathrm{y} ; \mathrm{Zn}, 1.08 \times 10^{5} \mathrm{t} / \mathrm{y} ; \mathrm{Ni}, 4.48 \times 10^{4} \mathrm{t} / \mathrm{y} ; \mathrm{Pb}, 4.32 \times 10^{4} \mathrm{t} / \mathrm{y} ;$ and $\mathrm{Cu}, 3.1 \mathrm{x}$

$1010^{4}$ t/y, respectively. Approximately 55-70\% and 10-17\% of the sedimentation fluxes

11 of trace metals were deposited in the inner shelf and the Changjiang estuarine zone.

12 (Keywords: continental shelf; East China Sea; enrichment factor; trace metals;

13 sediments; sedimentation flux)

14

15

16

17

18

19

20

21

22

23

\section{Introduction}

The East China Sea, located between $26^{\circ}-31^{\circ} \mathrm{N}$ and $121^{\circ}-126^{\circ} \mathrm{E}$, is one of the 
24 largest marginal seas in the western Pacific of the northern hemisphere, and it is also

25 the main discharge area of the Changjiang River which is the world's fourth largest

26 river when reviewed in terms of suspended load. The annual transportation of

27 suspended load of the Changjiang River is approximately $4.61 \times 10^{8} \mathrm{t} / \mathrm{y}$ (Zhang and

Liu, 2002). In addition, there are another four middle size rivers, namely the Jiaojiang,

the Qiantangjiang, the Jiulongjiang and the Minjiang, which together discharge $2.36 \mathrm{x}$

$10^{7}$ tons/y of suspended load into the ECS (Zhang and Liu, 2002). Along the coast

there are many developed cities, such as Shanghai and Ningbo, and a number of factories have also been set up there. Because of the over-emphasis on the economic development and the lack of environmental regulations since China embarked on the "Reform and Open Policy" from 1978, many studies have indicated that the Hangzhou Bay was contaminated by trace metals (Huh and Chen, 1999; Yuan et al., 2004) and polycyclic aromatic hydrocarbon (Guo et al., 2006). A recent study conducted in August 2003 uncovered a hypoxic area (dissolved oxygen concentrations $<2-3 \mathrm{mg} / \mathrm{l}$ ) greater than $12,000 \mathrm{~km}^{2}$ extending from the Changjiang River plume to the ECS (Chen et al., 2007). Thus, our current understanding is that the water quality of the ECS has been getting worse. However, the distribution and contamination status of trace metals for the whole ECS has not been established (Shi et al., 2005). In order to establish such a knowledge, the present study investigates the spatial distribution of trace metals in surface sediments of the ECS. In addition, based on the mass accumulation rates published in the literature for the ECS, the annual sedimentation fluxes of the studied metals in the ECS are also estimated. 
47

48

49

\section{Sampling and methods}

\subsection{Study area}

Twenty-five sediment cores were collected with a box core during a cruise onboard the R/V Ocean Research-I from 6-16 November, 2006. The box core was designed to obtain undisturbed sediments and the core samples were sealed and kept frozen for subsequent processing and analyzing in the university laboratory. The sampling stations (Fig.1) were located outside of the mouth of the Changjiang River and extended to the outer shelves of the ECS with water depths $<150 \mathrm{~m}$. Stations I1-I6 were located in the inner shelf and along the coast of China. Stations M1-M11 were situated in the middle shelf and extended southwards to the northern Taiwan Strait. Stations O1-O6 were located along the Okinawa Trough, through which the Kuroshio Water flows. To facilitate interpretation of the results, the sampling stations were divided into three groups based on their locations and bathymetry of the sampling sites: stations I1-I8 in the inner shelf (depth $<50 \mathrm{~m}$ ); stations M1-M11 in the middle shelf ( $50 \mathrm{~m}<$ depth $<100 \mathrm{~m}$ ); and stations O1-O6 in the outer shelf (100 $\mathrm{m}<$ depth $<150 \mathrm{~m})$.

The major source of the fine-grained sediment to the ECS continental shelf is from the Changjiang River, which discharges $4.61 \times 10^{8}$ t/y fine-grained sediment and accounts for $73 \%$ of the terrestrial export of suspended matter carried by rivers (Zhang and Liu, 2002). Most of the suspended sediments consist of silt and clay. A 
large portion of this sediment supply is moved southward by the Jian-Su coastal current (Cao et al., 1989). A small portion of the suspended sediments is transported east and northeastwards to the ESC (Sternberg et al., 1985). From the examination of ${ }^{210} \mathrm{~Pb}$ profiles in sediment DeMaster et al. (1985) obtained a sedimentation rate of up to $4.5 \mathrm{~cm} / \mathrm{y}$ near the mouth of the Changjiang River. In a recent study based on measurements of ${ }^{137}$ Cs throughout the ECS, Huh and Su (1999) indicated that the sedimentation rates in the ECS varied by two orders of magnitude, from 2 to 0.02 $\mathrm{cm} / \mathrm{y}$, and generally decreased southwards along the inner shelf and eastwards offshore. Based on the spatial distributions of the grain size, carbonate, organic carbon contents, metals/aluminum ratios and the $\delta C^{13}$ content of organic carbon, the ECS continental shelf was divided into five major regions: the Delta, inner shelf, middle shelf, outer shelf and northeast outer shelf (Lin et al., 2002). Major types of sediments occurring there include terrigenous sediments from the Changjiang River, relict sediment from the middle shelf, biogenic carbonate from the outer shelf and sediments from the Yellow Sea (Lin et al., 2002).

\subsection{Analytical method}

After thawing, the cores samples were extruded vertically with a hydraulic jack and sampled at $1 \mathrm{~cm}$ thickness at the surface. The outer rim $(\sim 0.5 \mathrm{~cm})$ of each sediment slab was trimmed off to avoid contamination between layers. Approximately 10-20 g of each surface sample $(0-1 \mathrm{~cm})$ was freeze-dried, ground and 


\section{ACCEPTED MANUSCRIPT}

90 homogenized with a mortar and pestle. The processed sample was stored in

91 acid-cleaned polypropylene tubes for further analysis. The bulk sediment samples

92 were divided into two sub-samples for the determinations of total organic carbon and

93 trace metals.

\section{Total organic carbon analysis}

Total organic carbon (TOC) contents in the sediment samples were measured by a

Horbia carbon analyzer 8210 after the samples were smoked with concentrated $\mathrm{HCl}$

acid in a closed container for 48 hours to remove the inorganic $\mathrm{C}$ content. The

detailed analytical procedure of TOC can be found in Fang and Hong (1999).

\section{Trace metals analysis}

102

The trace metals contents in the surface sediments were totally digested with

hydrofluoric acid (HF) in combination with aqua regia and heated on a hot plate at $200{ }^{\circ} \mathrm{C}$ for about 8 hours and evaporated to dryness. After cooling, the residue was dissolved with $0.5 \mathrm{ml} \mathrm{HNO}_{3}$ and the solution was made up with Milli-Q water to a volume of $25 \mathrm{ml}$ in a volumetric tube. The final acidic solution was transferred into a

$10750 \mathrm{ml}$ centrifuge tube and was centrifuged at a speed of $4000 \mathrm{rpm}$ for 5 minutes. The 108 clear supernatant was stored in acid-cleaned polypropylene tubes and was analyzed 109 for trace metals ( $\mathrm{Cu}, \mathrm{Fe}, \mathrm{Mn}, \mathrm{Ni}, \mathrm{Pb}$ and $\mathrm{Zn}$ ) by flame atomic absorption spectrometry using a Perkin-Elmer Analyst 800A. 
112 Analytical quality assurance was performed by measurements of the PACS-2

113 reference material (National Research Council of Canada). The concentrations ( $\mathrm{n}=6$ )

114 of trace metals measured in the PACS-2 reference material (one standard deviation)

115 were as follows: $\mathrm{Cu}, 286 \pm 14 \mu \mathrm{g} / \mathrm{g} ; \mathrm{Mn}, 412 \pm 18 \mu \mathrm{g} / \mathrm{g}$; Ni, $38.8 \pm 1.5 \mu \mathrm{g} / \mathrm{g} ; \mathrm{Pb}, 167$

$116 \pm 3 \mu \mathrm{g} / \mathrm{g}$; and $\mathrm{Zn}, 340 \pm 11 \mu \mathrm{g} / \mathrm{g}$, respectively. The ratio of the measured

117 concentration to the certified value and precision (one standard deviation) was as

118 follow: $\mathrm{Cu}, 92.6 \pm 4.0 \%$; $\mathrm{Mn}, 94.5 \pm 4.4 \%$; Ni, $98.3 \pm 4.0 \%$; Pb, $91.7 \pm 1.8 \%$; and $\mathrm{Zn}$, $119 \quad 93.4 \pm 3.4 \%$.

120

121 3. RESULTS AND DISCUSSION

$122 \quad 3.1$ Spatial distribution

123 The concentration ranges of TOC and trace metals in surface sediments of the ECS

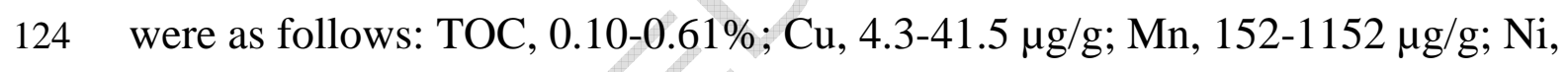

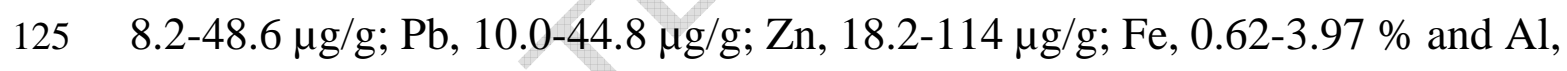

$1264.35-8.49 \%$, respectively. The concentrations of TOC and trace metals found at each

127 station are listed in Table 1 . The spatial distributions of TOC and trace metals are

128 shown in Fig.2. Higher concentrations of TOC and trace metals were generally found

129 on the inner shelf, especially the area off Hangzhou Bay. Away from the Hangzhou

130 Bay area, concentrations (except for $\mathrm{Mn}$ ) decreased in both a southerly (along the

131 inner shelf) and south-easterly (middle and outer shelves) direction. This finding is in

132 good agreement with TOC decreasing along transects radiating outwards from the

133 mouth of the Changjiang River. Therefore, it supports the view that Changjiang River 
134 is a dominant factor resulting in elevated trace metals and TOC concentrations on the

135 ECS (Lin et al., 2002) The spatial distributions of trace metals and TOC in the ECS

136 generally exhibited similar patterns and the concentration of TOC correlated well

137 with trace metals (Fig.3). It is well established that natural organic matter (NOM) has

138 a high affinity for trace metals in the aquatic environment (Stumm and Morgan,

139 1996). As a consequence, it affects the geochemical behavior of trace metal in the

140 aquatic environment. The coupling between the cycles of TOC and trace metals is

141 ultimately reflected in the chemical composition of marine sediments (Basaham and

142 El-Sayed, 1998; Fang and Hong, 1999; Lin et al., 2002).

144 In addition, the distribution of Mn showed a distinct peak situated between the

145 middle and outer shelves at approximately located at $27^{\circ} \mathrm{N}$ and $123.5^{\circ} \mathrm{E}$. The

146 mechanism caused such a distribution is probably due to the sediment of this area

147 being dominated by biogenic carbonate (Lin et al., 2002). Previous studies have

148 shown that dissolved manganese can become adsorbed on, or incorporated into,

149 freshly precipitated $\mathrm{CaCO}_{3}$ in seawater (e.g. Wartel et al., 1990). Wartel et al. (1990,

150 1991) used suspended particulate matters from the English Channel, which is high in

151 carbonate minerals, to study the interaction of $\mathrm{Mn}^{+2}$ in the $\mathrm{CaCO}_{3}$ structure. They

152 concluded that the adsorption on and substitution in calcite are the major mechanisms

153 controlling the dissolved concentration of Mn in seawater along the French coast of

154 the English Channel. Recent studies on suspended particulate matter from the Seine

155 Estuary have also indicated that the majority of particulate Mn is bound to carbonate 
156 (Boughriet et al., 1992; 1994). A good correlation between concentrations of Mn and

157 carbonate in marine sediments has been reported off the southwestern coast of

158 Taiwan (Fang and Hong, 1999).

159

160

Total concentrations of trace metals in the inner shelf sediment found in the present

161 study were in good agreement with the report by Yuan et al. (2004) who used the

162 four-step sequential extraction procedure to analyze coastal sediments outside of the

163 Changjiang Estuary. Their results also indicated that more than $90 \%$ of $\mathrm{Fe}$ and

$16460-80 \%$ of $\mathrm{Cu}, \mathrm{Ni}$ and $\mathrm{Zn}$ total concentrations were present in the residual fraction. In

165 contrast, the concentrations of $\mathrm{Mn}$ and $\mathrm{Pb}$ were dominant in the non-residual fraction,

166 accounting for more than $60 \%$ of the total concentrations. A comparison of trace

167 metals concentrations in shelf sediments around the world is given in Table 2. It can

168 be seen that the concentrations of trace metals, except Mn, found in the continental

169 shelves, such as the Arabian Gulf, the Mediterranean Sea, the Aegean Sea and the

170 Laptev Sea, around the world are quite comparable. However, the average

171 concentration of Mn found in the ECS is two-three folds higher than those of the

172 above continental shelves. Comparably high concentrations of Mn have been reported

173 by Nolting et al. (1996) who indicated that Mn lateral distribution in surface

174 sediments showed an increase from $1000 \mu \mathrm{g} / \mathrm{g}$ in the mouth of the Lena River to >

$1755000 \mu \mathrm{g} / \mathrm{g}$ in the eastern part of the Laptev Sea. They attributed these higher

176 concentrations to the diagenetic process in sediments which caused large upward

177 fluxes of Mn. The findings of Nolting et al. (1996) elucidate that trace metal, especial 


\section{ACCEPTED MANUSCRIPT}

178 the redox sensitive metal like $\mathrm{Fe}$ and $\mathrm{Mn}$, contents in marine sediments may increase

179 several folds through the naturally geochemical process regardless of the

180 anthropogenic influence.

182

184

185

186

187

188

189

190

191

192

193

194

195

196

197

198

199

\subsection{Enrichment factor}

Trace metals concentrations in marine surface sediments can vary widely (Luoma, 1990). As a result, it is difficult to evaluate whether the observed concentration in marine sediments is influenced by anthropogenic sources or not without normalizing the result. Some normalising procedures are widely used to compensate for differences in grain size variations and carbonate content, and thus provide a means of separating anthropogenic sources from natural inputs (Luoma, 1990). Normalization to a background level of metals in samples with different characteristics can be accomplished by calculating an enrichment factor (EF) relative to the reference sample. In the equation

$$
\mathrm{EF}=(\mathrm{M} / \mathrm{Al})_{S} /(\mathrm{M} / \mathrm{Al})_{R}
$$

$(\mathrm{M} / \mathrm{Al})_{S}$ and $(\mathrm{M} / \mathrm{Al})_{\boldsymbol{R}}$ are the ratio of metal to $\mathrm{Al}$ concentrations in sample and in reference sample, respectively. It is found that the metal concentrations at stations of the outer shelf in the ECS were the least among the study areas, which may indicate that the disturbance of the outer shelf was relatively minor. In order to avoid the natural differences of sediment textures in different environments, the reference sample is taken from the data of outer shelf stations in the present study. The average concentrations of each metal and $\mathrm{Al}$ at all stations of outer shelf are considered as the 
200 reference values which are used to calculate the EF and assess the contamination

201 status of the ECS. The EF range of the studied metals was as follow: Fe, 0.43-1.93

202 (average 1.22); $\mathrm{Cu}, 0.67-5.83$ (average 1.96); Mn, 0.54-3.76 (average 1.47); Ni, 203 0.52-2.57 (average 1.42); Pb, 0.56-2.07(average 1.29); and $\mathrm{Zn}, 0.51-2.89$ (average 204 1.42). Contour plots of EF distribution for each metal are shown in Fig.4. 205 Surprisingly, the $\mathrm{EF}$ values of $\mathrm{Cu}$ are the highest and indicate a marked 206 anthropogenic burden, suggesting that $\mathrm{Cu}$ was the most contaminated metal among 207 the studied metals. However, it can be seen in Fig.4 that the contour values of each 208 metal greater than 2 generally distributed in the inner shelf. While, the contour values 209 in the middle and outer shelves are within the range of 1-2 and approache to 1 , 210 respectively. The EF values suggest the inner shelf of the ECS was mildly 211 contaminated by trace metals. Such a metal contamination did not further extend to 212 the middle and outer shelves.

An EF value of 1 indicates a predominantly natural origin for the element in 215 sediment, while values greater than 1.5 indicate enrichment by either natural 216 processes (e.g. biota contributions) or anthropogenic influences (Zhang and Liu, 217 2002). EF values lower than 0.5 can reflect mobilization and loss of these elements 218 relative to $\mathrm{Al}$, or indicate an overestimation of the reference metal contents (Zhang, 219 1995; Mil-Homens et al., 2006). 
222 Huh and coworker employed the radionuclide method $\left({ }^{210} \mathrm{~Pb},{ }^{137} \mathrm{Cs}\right.$ and $\left.{ }^{239,240} \mathrm{Pu}\right)$ to 223 comprehensively evaluate the sedimentation rates and mass accumulation rates in the 224 East China Sea (Huh and Su, 1999; Su and Huh, 2002). Based on their data and trace 225 metals concentrations in surface sediment found in the present study, an attempt is 226 made to calculate the trace metals sedimentation fluxes in the ECS. To facilitate the 227 calculation, the calculated area is divided into five boxes: estuary (box I), inner shelf 228 (box II), middle shelf (box III and IV), and outer shelf (box V) (Fig. 5), according to 229 the value of mass accumulation rate (MAR) in each box observed by Huh and 230 coworker (Huh and Su, 1999; Su and Huh, 2002). The middle shelf area is divided 231 into two boxes because the MAR in the northern middle shelf slightly differed from 232 the southern middle shelf.

Due to the ECS being adjacent to the Yellow Sea to the north and with the North 235 Pacific Ocean to the east, its total area is difficult to determine. Two widely accepted 236 values are $0.74 \times 10^{6} \mathrm{~km}^{2}$ for the total area of the ECS and $0.51 \times 10^{6} \mathrm{~km}^{2}$ for the area 237 with a water depth $<200 \mathrm{~m}$ (Wong et al., 2000, and references cited therein). The 238 calculated area of the present study is approximately $0.376 \times 10^{6} \mathrm{~km}^{2}$, which accounts 239 for about 50\% of the whole ECS area provided by Wong et al. (2000) and about 74\% 240 of the continental shelf area. Table 3 shows the area, the concentration range of trace 241 metals obtained in the present study and the mass accumulation rate (MAR) in each 242 box. 
There are three values for each metal-related parameter: minimum, maximum and

245

246

247

248

249 250

251

252

253

254

255

average. The minimum value of the annual metals sedimentation flux was calculated from the minimum concentration of metals multiplied the minimum value of MAR in each box. The maximum and average values were calculated in a similar manner. The average annual sedimentation fluxes of trace metals in the calculated area were as follow: Fe, 34800 x $10^{9} \mathrm{~g} / \mathrm{y} ; \mathrm{Mn}, 907$ x $10^{9} \mathrm{~g} / \mathrm{y} ; \mathrm{Cu}, 31.0$ x $10^{9} \mathrm{~g} / \mathrm{y} ; \mathrm{Ni}, 44.8$ x $10^{9} \mathrm{~g} / \mathrm{y}$; $\mathrm{Pb}, 43.2 \times 10^{9} \mathrm{~g} / \mathrm{y}$; and $\mathrm{Zn}, 108 \times 10^{9} \mathrm{~g} / \mathrm{y}$. Most of the sedimentation fluxes of trace metals were concentrated in the inner shelf (box II), accounting for $55-70 \%$ of the total fluxes of each metal. The second important area was the estuarine zone (box I), contributing from 10 to $17 \%$ of the total fluxes of each metal. These results indicate that the suspended loads of metals exported from the Changjiang River catchment were mostly deposited on the inner shelf. It is well known that the continental shelf sediments originate primarily from the riverine suspended load. The suspended load of the Changjiang River is the major contribution and the four middle size rivers, namely the Jiaojiang, the Qiantangjiang, the Jiulongjiang and the Minjiang, contribute minor inputs to the ECS (Zhang and Liu, 2002). The upper part of Table 4 summarizes the annual flux of particles to the coast and their trace metal contents. The calculated annual chemical fluxes of particulate metals from these rivers are listed in the lower part of Table 4. These fluxes are as follows: Fe, 24456 x $10^{9} \mathrm{~g} / \mathrm{y}$; Mn, 386.6 x $10^{9}$ g/y; Cu, 29.97 x $10^{9}$ g/y; Ni, 30.67 x $10^{9}$ g/y; Pb, 19.87 x $10^{9}$ g/y; and $\mathrm{Zn}, 46.67 \times 10^{9} \mathrm{~g} / \mathrm{y}$. 


\section{ACCEPTED MANUSCRIPI}

These riverine fluxes of particulate metals are generally lower than, but with the

267 same magnitude as, the calculated sedimentation fluxes. The reason for this 268

enrichment factor values. The calculation bias of sedimentation fluxes could also be another reason because the difference of maximum and minimum values may vary one order of magnitude. However, the data accuracy of the riverine sediment transportation fluxes and properties shown in literature (Zhang and Liu, 2002, and references cited therein) should be taken into account when calculating the riverine annual transportation fluxes. Since the riverine data were established in the early 1990s. It is known that China launched its modernization campaign from 1980 and substantially increased its economic development in the last two decades (Guo et al., 2006). The rapid economic development of China may alter the environment. One of the evidences is that the Asian dust storm which occurred since 2000 (Mori et al., 2003). Thus, in order to obtain a more accurate calculation of the riverine annual fluxes of trace metals, the updating riverine data are necessary to be used. Unfortunately, it is not able to find the updating data in the literature.

\subsection{Atmospheric trace metals flux}

Owing to its rapid industrial development and urbanization since 1980, the frequency and scale of dust events giving rise to dust storm aerosols has increased suffer from the dust storms which annually occur in the late winter and spring in this 
decade. Asian dust storms, generated when the surface soil in the arid region of the Asian continental landmass is lifted by winds, move southeastward out of the China continent, the northeasterly monsoon prevails south of $30^{\circ} \mathrm{N}$ following the passage of the cold front (Hsu et al., 2008). Zhang et al (1997) estimated China’s annual emission of dusts to be $\mathrm{Tg}, 50 \%$ of which is subject to long-range transport to the Pacific Ocean and beyond. The East China Sea is situated the right pathway of the Asian dust storms. As a result, it is expected that the atmospheric dry deposition may provide a substantial amount of chemical constituents to the East China Sea.

Research into Asian dust storms impact on the biogeochemistry of the ECS, especially with respect to biological bloom and budget balance of nutrients and trace metals, has been conducted by several research groups (Yuan and Zhang, 2006; Hsu et al., 2008). A comprehensive study carried out by Hsu et al (2008) who conducted several cruises to collect the marine aerosols from the ECS during the spring of 2005 and 2007. They analyzed marine aerosol samples for both the water-soluble and the total concentration of 27 trace elements and calculated the dry deposition fluxes.

Their results for trace metals dry deposition fluxes were as follows: Fe, $39 \pm 50$ $\mu \mathrm{g} / \mathrm{m}^{2} / \mathrm{d} ; \mathrm{Cu}, 12 \pm 14 \mu \mathrm{g} / \mathrm{m}^{2} / \mathrm{d} ; \mathrm{Mn}, 6.7 \pm 14.3 \mu \mathrm{g} / \mathrm{m}^{2} / \mathrm{d} ; \mathrm{Ni}, 0.24 \pm 0.29 \mu \mathrm{g} / \mathrm{m}^{2} / \mathrm{d} ; \mathrm{Pb}$, $2.5 \pm 6.7 \mu \mathrm{g} / \mathrm{m}^{2} / \mathrm{d}$; and $\mathrm{Zn}, 19 \pm 39 \mu \mathrm{g} / \mathrm{m}^{2} / \mathrm{d}$. We used these values to calculate 120 -day and 180-day of the aerosol dry deposition fluxes of these metals in same area, $0.376 \mathrm{x}$ $10^{6} \mathrm{~km}^{2}$, as the calculation of metals sedimentation fluxes in the ECS, as shown above. The calculated result for the aerosol dry deposition fluxes and the riverine 
annual transportation fluxes of these metals are depicted together in Fig. 6.

311 Surprisingly, the aerosol dry deposition fluxes of these metals are relatively small

312 compared with the riverine annual fluxes. The percentage of 120-day aerosol dry

313 deposition fluxes of these metals to the riverine annual fluxes is as follows: $\mathrm{Cu}$ and

314 Zn, 1.8\%; Pb, 0.56\%; Mn, 0.08\%; Ni, 0.035\%; and Fe, 0.007\%. This result may

315 suggest that the aerosol dry deposition fluxes of Fe, Mn, Ni and Pb can be ignored,

316 and of $\mathrm{Cu}$ as well as $\mathrm{Zn}$ contribute a small amount of fluxes to the ECS when

317 comparing with the riverine fluxes.

\section{Conclusions}

The water quality of the ECS has been getting deleterious due to the rapid

industrial development and urbanization of China since 1980. However, the results of

this study find that the surface sediment of the inner shelf of the East China Sea was

mildly contaminated by trace metals. Elevated concentrations of trace metals were

generally found in the Hangzhou Bay and along the inner shelf of the ECS. Trace

metals contamination did not extend further to the middle and outer shelves of the

ECS. The combination of two effects may explain this finding. First, more than $80 \%$

the sedimentation fluxes of trace metals are deposited in the inner shelf and the

Changjiang estuarine zone. Secondly, the atmospheric dry deposition fluxes of trace metals to the ECS are relatively small compared with the riverine annual fluxes. 


\section{ACCEPTED MANUSCRIPT}

332 are generally higher than those of the riverine annual transportation fluxes of

333 particulate metals. The anthropogenic source is probably the major mechanism.

334 However, the use of the old published data of the riverine particulate composition and

335 flux in literature to calculate the riverine annual fluxes may cause under estimation

336 because the environmental changes may occur substantially due to the rapid industrial

337 development and urbanization in China.

338

339

340

341

342

343

344

345

346

347

348

349

350

351

352

353 
359 We wish to gratefully acknowledge the assistance provided by the captain and 360 crew of the R/V Research-I during sampling. The authors are grateful to two 361 anonymous referees for their constructive comments and suggestions which led to 362 significant improvements to the manuscript. This research was financially supported 363 by the National Science Council of the Republic of China under grants NSC 


\section{REFERENCES}

380

381

382

383

384

385

386

387

388

389

390

391

392

393

394

395

Aloupi, M., Angelidis, M.O., 2001. Normalization to lithium for the assessment of metal contamination in coastal sediment cores from the Aegean Sea, Greece. Marine Environmental Research 52, 1-12.

Basaham, A.S., El-Sayed, M.A., 1998. Distribution and phase association of some major and trace elements in the Arabian Gulf sediments. Estuarine, Coastal and Shelf Science 46, 185-194.

Bougheriet, A., Ouddane, B., Fischer, J.C., Wartel, M., Leman, G., 1992. Variability of dissolved Mn and $\mathrm{Zn}$ in the Seine estuary and chemical speciation of these metals in suspended matter. Water Research 26, 1359-1378.

Bougheriet, A., Wartel, M., Cordier, C., Douez, C., Deram, L., Martin, E., Ouddane, B., Chamley, H., Recourt, P., 1994. Chemical speciation of some particulate elements in the English Channel, and impact of human activities on the magnetic behavior of suspended matter. Marine Pollution Bulletin 28, 541-556. 


\section{ACCEPTED MANUSCRIPT}

398

399

400

401

402

403

404

405

406

407

408

409

410

411

412

413

414

415

416

417

418

419

Cao, P., Huo, F., Gu, G., Zhou, Y., 1989. Relationship between suspended sediments

from the Changjiang estuary and the evolution of the embayed muddy coast of

Zhejinag Province. Acta Oceanol Sinica 8, 273-283.

Chen, C.C., Gong, G.C., Shiah, F.K., 2007. Hypoxia in the East China Sea: One of largest coastal low-oxygen areas in the world. Marine Environmental Research 64, 399-408.

DeMaster, D., Mckee, B., Nittrouer, C., Qian, J., Cheng, G., 1985. Rates of sediment accumulation and particle reworking based on radiochemical measurements from continental shelf deposits in the East China Sea. Continental Shelf Research 4, 143-158.

Fang, T.H., Hong, E., 1999. Mechanisms influencing the spatial distribution of trace metals in surficial sediments off the south-western Taiwan. Marine Pollution Bulletin $38,1026-1037$.

Goldsmith, S.L., Krom, M.D., Sandler, A., Herut, B., 2001. Spatial trends in the chemical composition of sediments on the continental shelf slope off the Mediterranean coast of Israel. Continental Shelf Research 21, 1879-1900. 


\section{ACCEPTED MANUSCRIPT}

420 depositional record of polycyclic aromatic hydrocarbons in the central continental

421 shelf mud of the East China Sea. Environmental Science \& Technology 40,

$422 \quad 5304-5311$.

423

424 Hsu, S.C., Wong, G.T.F., Gong, G.C., Shiah, F.K., Huang, Y.T., Kao, S.J., Tsai, F.,

425 Lung, S.C., Lin, F.J., Lin, I.I., Hung, C.C., Tseng, C.M., 2008. Source, solubility, and

426 dry deposition of aerosol trace elements over the East China Sea. Marine Chemistry, 427 doi:10.1016/j.marchem.2008.10.003.

428

429

Huh, C.A., Chen, H. Y., 1999. History of lead pollution recorded in East China Sea 430 sediments. Marine Pollution Bulletin 38, 545-549.

431

432 Huh, C. A., Su, C., 1999. Sedimentation dynamics in the East China Sea elucidated 433 from ${ }^{210} \mathrm{~Pb},{ }^{137} \mathrm{Cs}$ and ${ }^{239,240} \mathrm{Pu}$. Marine Geology 160, 183-196.

434

435

Lin, S., Huang, K., Chen, S., 2002. Sulfate reduction and iron sulfide mineral 436 formation in the southern East China Sea continental slope sediment. Deep Sea

Research I 49, 1837-1852. 
442

443

444 Environment, CRC Press Inc., Boca Raton, pp.51-66.

445

446

447

448

449

450

451 for surface sediments from three areas of the Portuguese continental shelf.

452 Continental Shelf Research 26, 1184-1205.

453

454

455

456

457

458

459

460

461

462 Nolting, R.F., van Dalen, M., Helder, W., 1996. Distribution of trace and major

463 elements in sediment and pore waters of the Lena Delta and Laptev Sea. Marine 
464

465

466

467 468 469 470 471 472 473 474 475 476

477 478

479 480 481 482

483

484 485

Chemistry 53, 285-299.

Nolting, R.F., Ramkema, A., Everaarts, J.M., 1999. The geochemistry of Cu, Cd, Zn, $\mathrm{Ni}$ and $\mathrm{Pb}$ in sediment cores from the continental slope of the Banc d'Arguin (Mauritania). Continental Shelf Research 19, 665-691.

Shi, J., Liang, L., Yuan, C., He, B., 2005. Methylmercury and total mercury in sediments collected from the East China Sea. Bull. Environmental Contamination Toxicology 74, 980-987.

Sternberg, R., Larson, L., Miao, Y., 1985. Tidally driven sediment transport on the East China Sea continental shelf. Continental Shelf Research 5, 105-120.

Stumm, W., Morgan, J., 1996. Aquatic Chemistry. $3^{\text {rd }}$ ed. A Wiley-Interscience Publication, John Wiley \& Sons, Inc.

Su, C., Huh, C., 2002. ${ }^{210} \mathrm{~Pb},{ }^{137} \mathrm{Cs}$ and ${ }^{239,240} \mathrm{Pu}$ in the East China Sea sediments: sources, pathways and budgets of sediments and radionuclides. Marine Geology 183, 163-178.

Wartel, M., Skiker, M., Auger, Y., Boughriet, A., 1990. Interaction of manganese (II)

85 with carbonates in seawater: assessment of the solubility product of $\mathrm{MnCO}_{3}$ and $\mathrm{Mn}$ 


\section{ACCEPTED MANUSCRIPT}

486 distribution coefficient between the liquid phase and $\mathrm{CaCO}_{3}$ particles. Marine

487 Chemistry 29, 99-117.

488

489

Wartel, M., Skiker, M., Auger, Y., Boughriet, A., Puskaric, E., Guegueniat, P., 1991.

490

Seasonal variation of $\mathrm{Mn}^{+2}$ adsorption on to calcareous surfaces in the English

491

Channel, and its implication on the manganese distribution coefficient. Marine

492

Chemistry 36, 85-105.

493

494

Wong, G., Chao, S., Li, Y., Shiah, F., 2000. The Kuroshio Edge Exchange Processes

495

(KEEP) study - an introduction to hypotheses and highlights. Continental Shelf

Research 20, 335-347.

497

498

Yuan, C., Shi, J., He, B., Liu, J., Liang, L., Jiang, G., 2004. Speciation of heavy

499

metals in marine sediments from the East Chia Sea by ICP-MS with sequential

500

extraction. Environmental International 30, 769-783.

501

502

Yuan, W., Zhang, J., 2006. High correlations between Asian dust events and

503

biological productivity in the western North Pacific. Geophysical Research Letters 33,

504

L07603. doi:10.1029/2005GL025174.

505

Zhang, J., 1995. Geochemistry of trace metals from Chinese river/estuary system: An overview. Estuarine, Coastal and Shelf Science 41, 631-658. 
508 particulate metals in China-weathering features, anthropogenic impact and chemical

509 fluxes. Estuarine Coastal Shelf Science 45, 1051-1070.

510

511 Zhang, X.Y., Arimoto, R., An, Z.S., 1997. Dust emission from Chinese desert sources

512 linked to variations in atmospheric circulation. Journal of Geophysical Research 102,

$513 \quad 28041-28047$. 
517 Fig.1. Map showing sampling stations in the East China Sea.

518 Fig.2. Spatial variation of trace metals concentrations in the surface sediment in the study area of the East China Sea.

Fig.3 Scatter plot between concentrations of TOC and trace metals and their correlation

Fig.4. Spatial variation of enrichment factor of trace metals in the study area of the East China Sea.

Fig.5. Sub-areas, as defined on the basis of sedimentation rates, and trace metal content. These sub-areas are: (I) estuary; (II) inner shelf; (III) middle shelf; (IV) middle shelf; and (V) outer shelf

Fig.6. Comparison of the riverine annual transportation fluxes of trace metals with Asian dusts dry deposition fluxes of trace metals (120-day and 180-day) to the East China Sea. 


\section{ACCEPTED MANUSCRIPT}

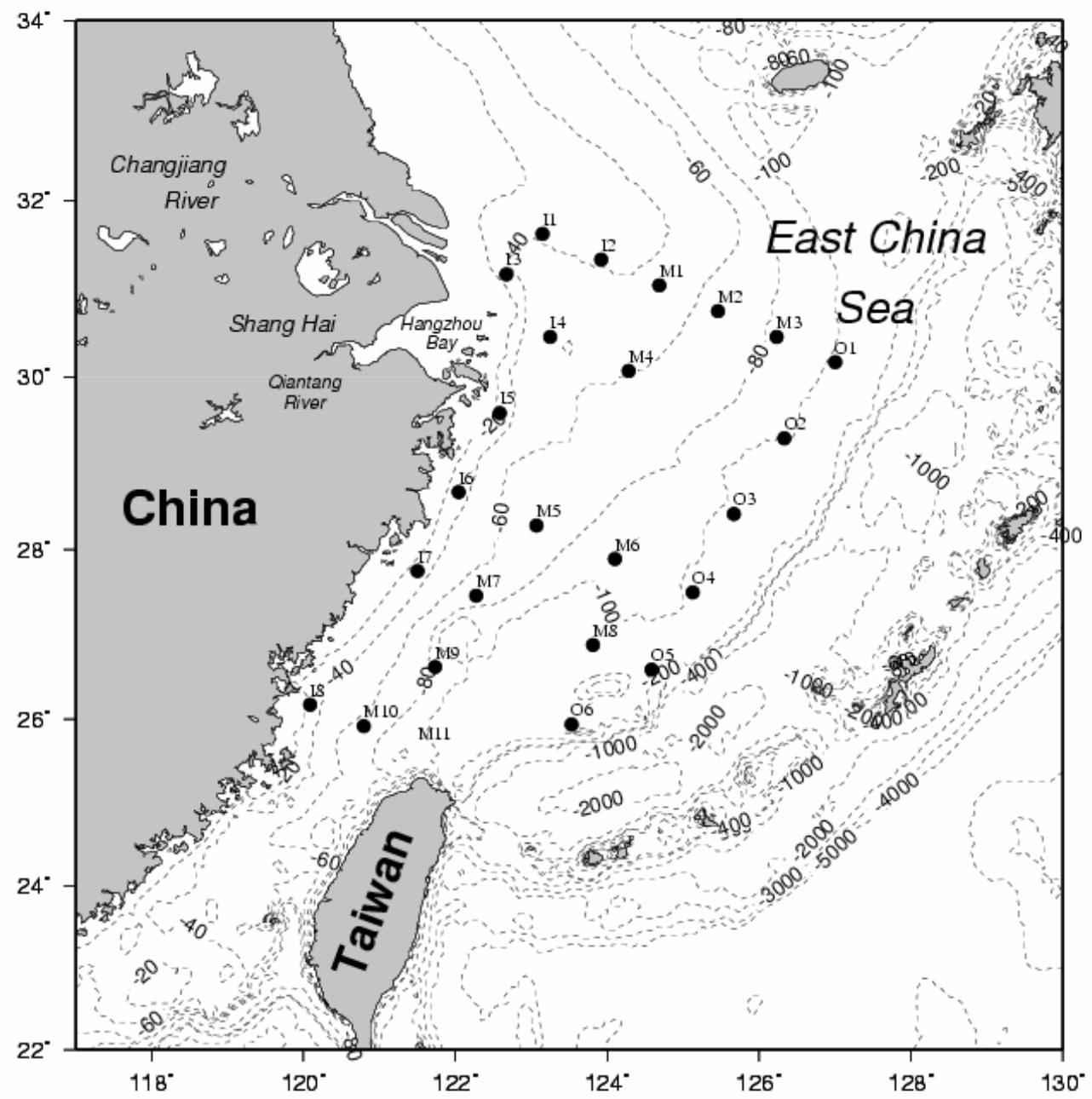

542

543

Fig.1

544

545

546

547

548

549

550

551

552 

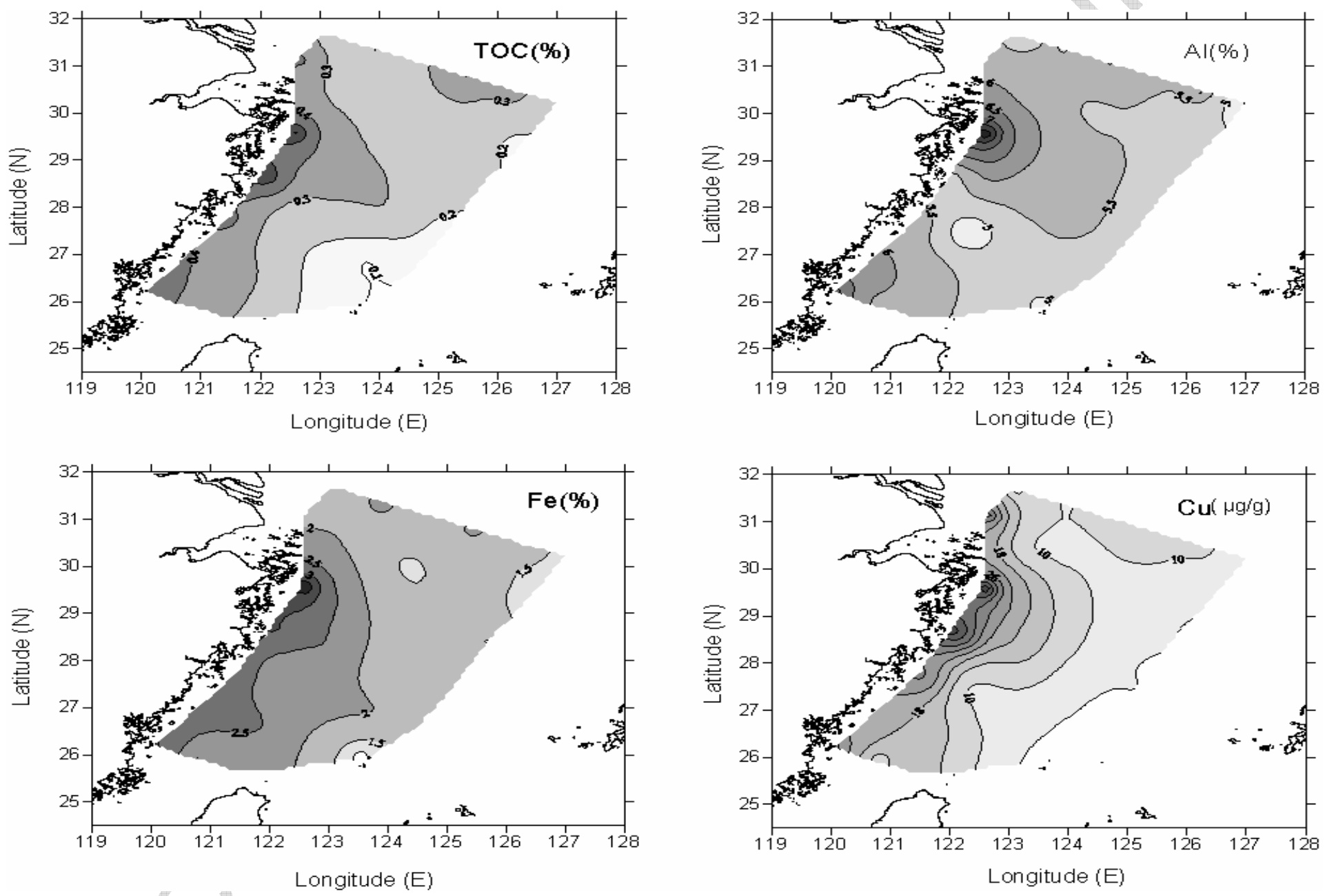

Fig.2 

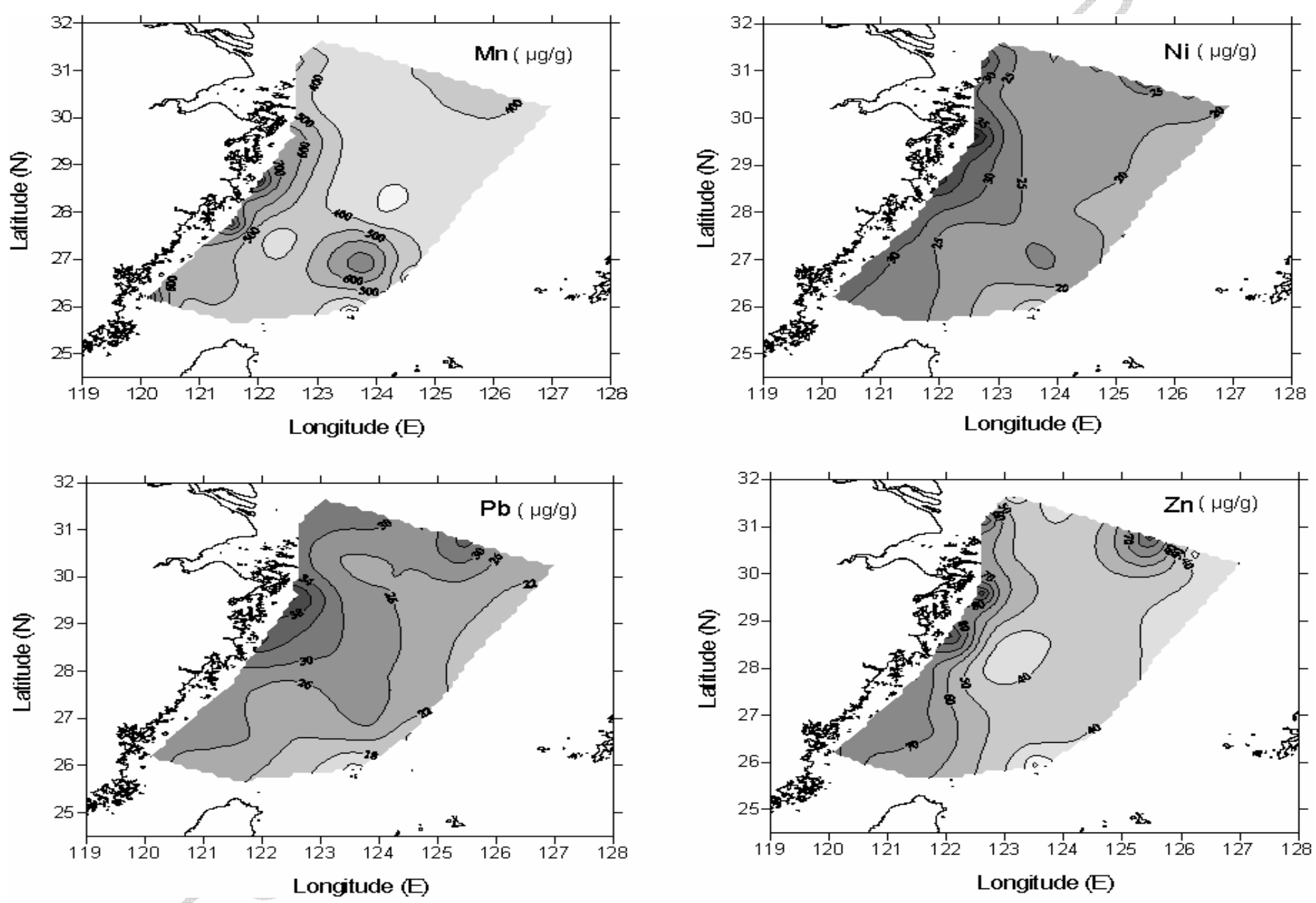

Fig.2 Continue 


\section{ACCEPTED MANUSCRIPT}
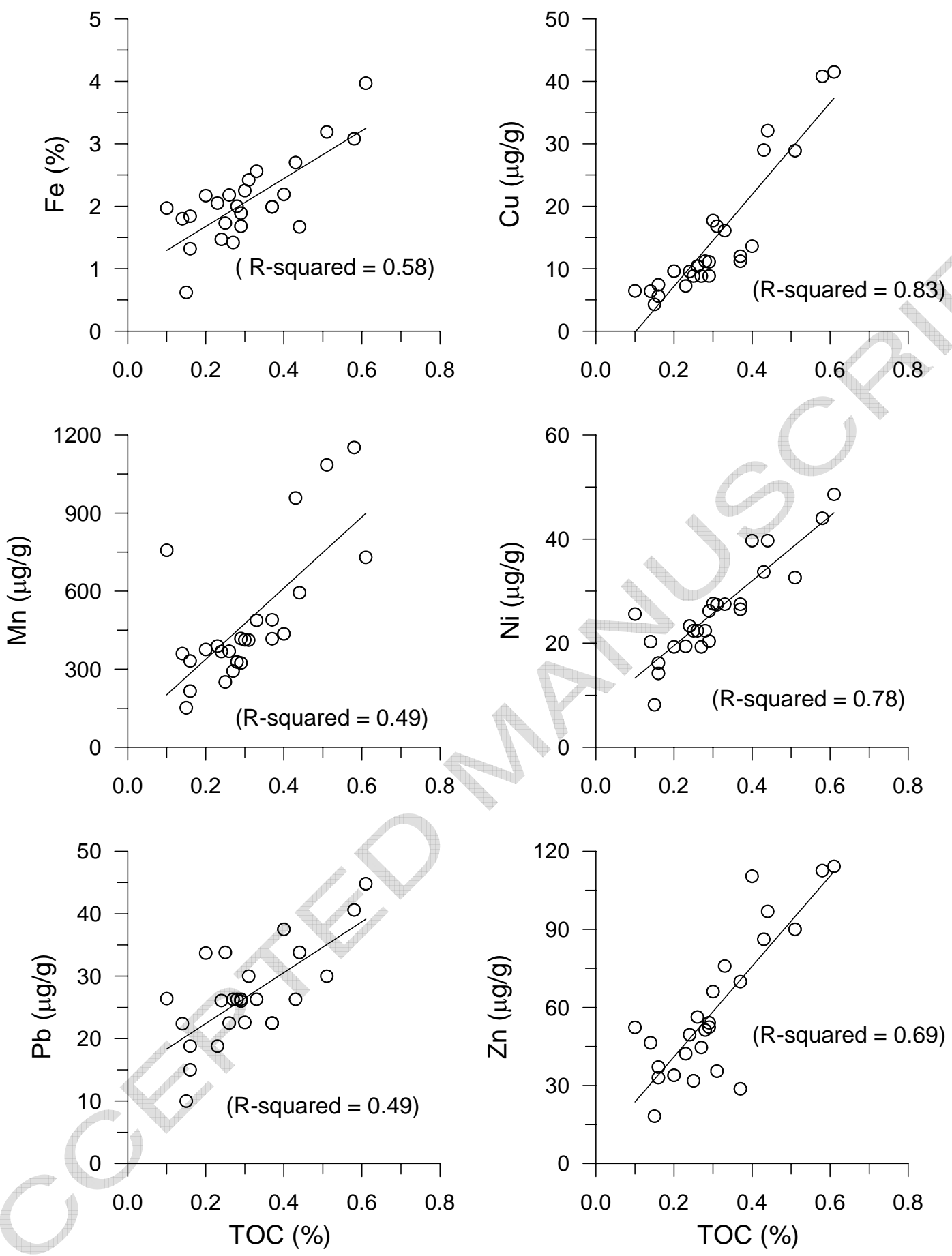

Fig. 3 

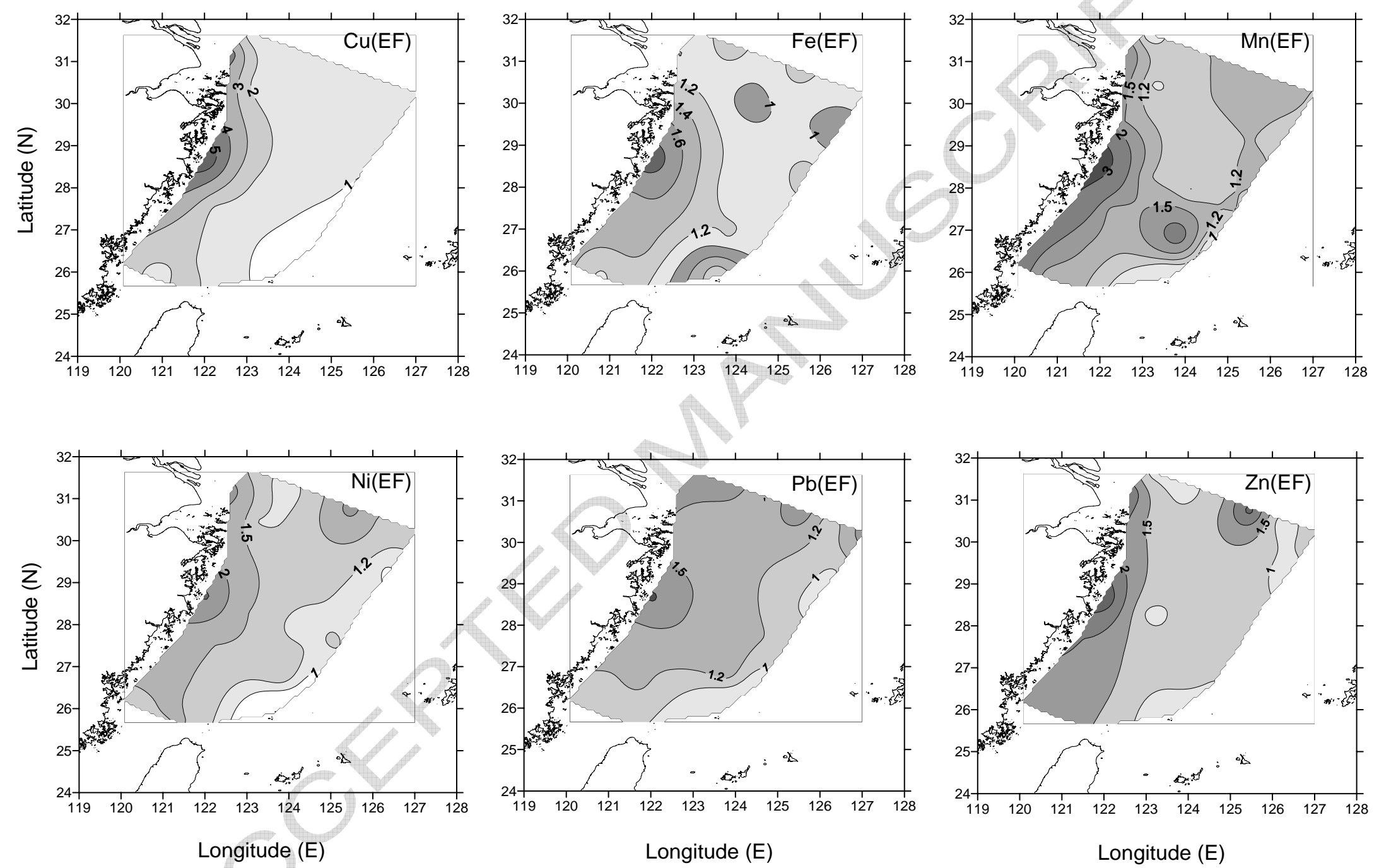

Fig.4 


\section{ACCEPTED MANUSCRIPT}

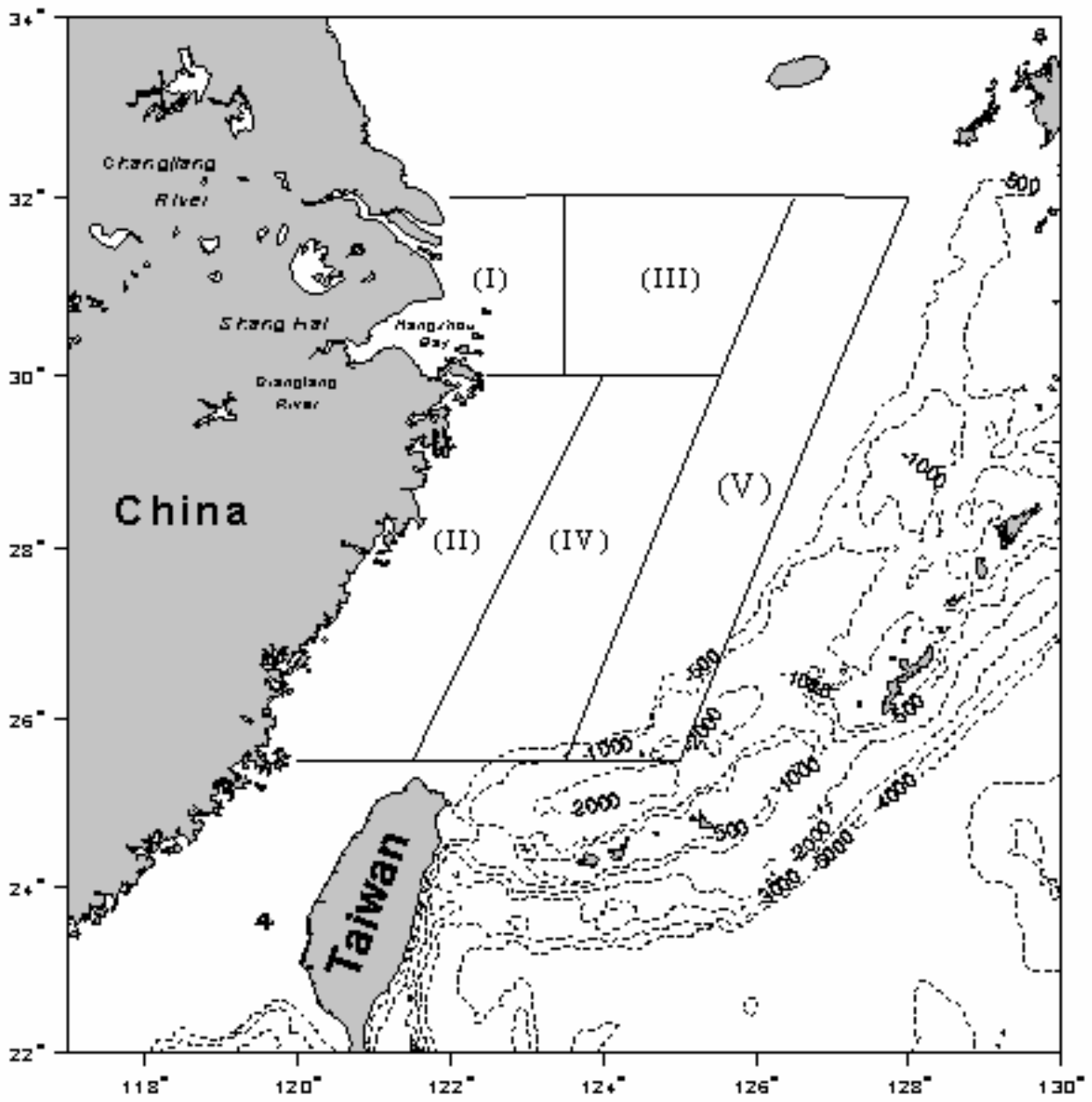

Fig.5

3

4

5

6

7

8

9

10

11

12

13

14 


\section{ACCEPTED MANUSCRIPT}

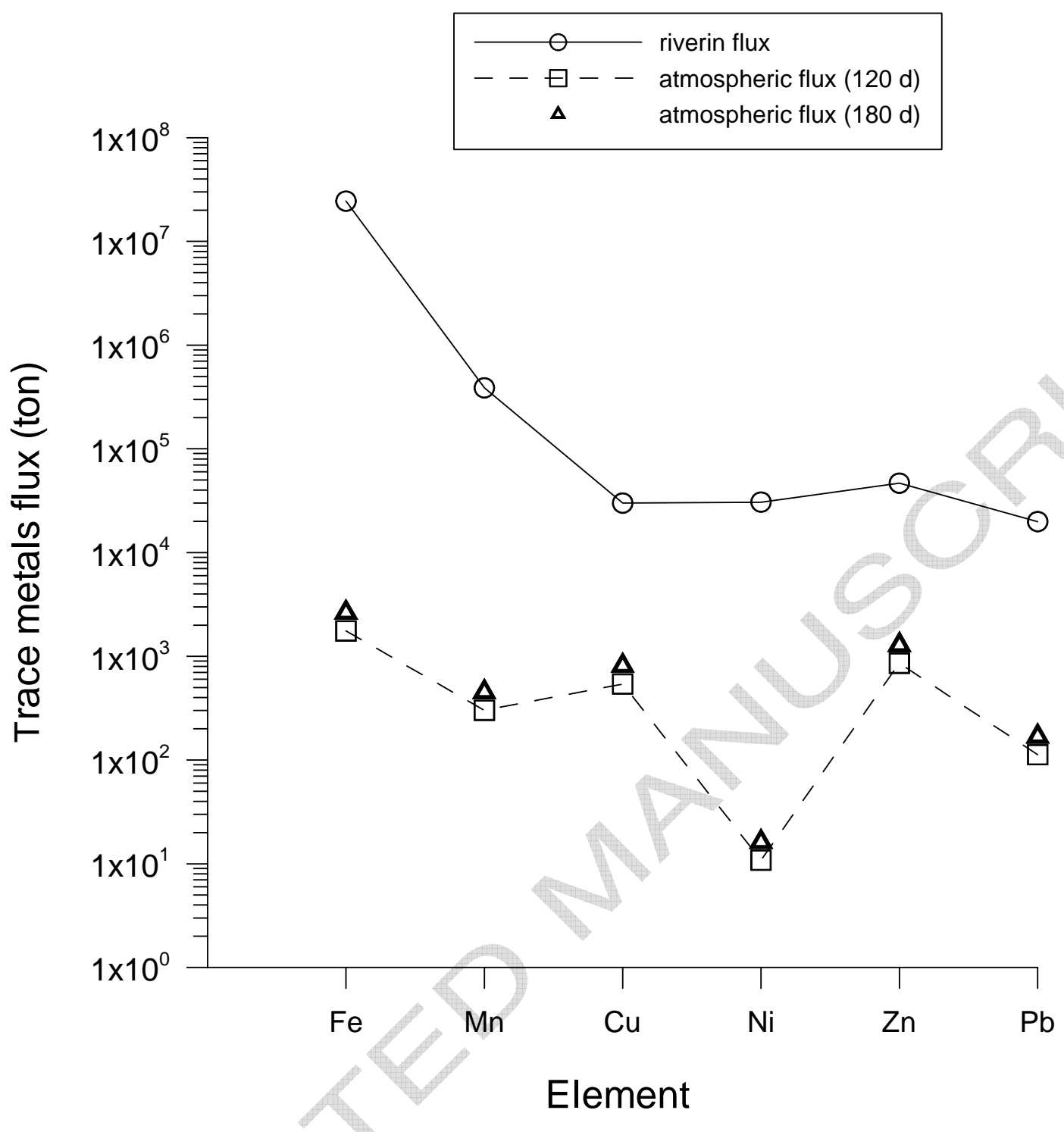

Fig. 6

19 
21 Table 1. The concentrations of trace metals in surface sediments at the study stations 22 in the East China Sea.

23

\begin{tabular}{|c|c|c|c|c|c|c|c|c|c|c|}
\hline Station & Long.(E) & Lat. (N) & $\begin{array}{l}\text { TOC } \\
(\%)\end{array}$ & $\begin{array}{c}\mathrm{Al} \\
(\%)\end{array}$ & $\begin{array}{c}\mathrm{Fe} \\
(\%)\end{array}$ & $\begin{array}{c}\mathrm{Cu} \\
(\mu \mathrm{g} / \mathrm{g})\end{array}$ & $\begin{array}{c}\mathrm{Mn} \\
(\mu \mathrm{g} / \mathrm{g})\end{array}$ & $\begin{array}{c}\mathrm{Ni} \\
(\mu \mathrm{g} / \mathrm{g})\end{array}$ & $\begin{array}{c}\mathrm{Pb} \\
(\mu \mathrm{g} / \mathrm{g})\end{array}$ & $\begin{array}{c}\mathrm{Zn} \\
(\mu \mathrm{g} / \mathrm{g})\end{array}$ \\
\hline I1 & $123^{\circ} 8.75^{\prime}$ & $31^{\circ} 37.49^{\prime}$ & 0.25 & 5.12 & 1.73 & 8.83 & 251 & 22 & 33.8 & 31.8 \\
\hline I2 & $123^{\circ} 55.00^{\prime}$ & $31^{\circ} 20.00^{\prime}$ & 0.20 & 5.47 & 2.17 & 9.61 & 376 & & 33.7 & 33.9 \\
\hline I3 & $122^{\circ} 40.00^{\prime}$ & $31^{\circ} 10.00^{\prime}$ & 0.44 & 5.67 & 1.67 & 32.1 & 594 & 39.7 & 33.8 & 96.9 \\
\hline I4 & $123^{\circ} 15.00^{\prime}$ & $30^{\circ} 27.50^{\prime}$ & 0.28 & 5.84 & 2.00 & 11.2 & 328 & 22.4 & 26.3 & 51.3 \\
\hline I5 & $122^{\circ} 35.00^{\prime}$ & $29^{\circ} 35.00^{\prime}$ & 0.61 & 8.49 & 3.97 & 41.5 & & 48.6 & 44.8 & 114.2 \\
\hline I6 & $122^{\circ} 2.50^{\prime}$ & $28^{\circ} 40.00^{\prime}$ & 0.58 & 5.33 & 3.08 & 40.8 & 1152 & 44.0 & 40.6 & 112.6 \\
\hline I7 & $121^{\circ} 30.00^{\prime}$ & $27^{\circ} 45.00^{\prime}$ & 0.43 & 5.83 & 2.70 & 29.0 & 958 & 33.7 & 26.3 & 86.2 \\
\hline I8 & $120^{\circ} 5.00^{\prime}$ & $26^{\circ} 10.00^{\prime}$ & 0.51 & 7.44 & 3.19 & 28.9 & 1085 & 32.6 & 30.0 & 90.0 \\
\hline M1 & $124^{\circ} 41.25^{\prime}$ & $31^{\circ} 2.50^{\prime}$ & 0.29 & 6.03 & 1.89 & 11.1 & 418 & 26.2 & 26.0 & 54.1 \\
\hline M2 & $125^{\circ} 27.50^{\prime}$ & $30^{\circ} 45.00^{\prime}$ & 0.40 & 5.63 & 2.19 & 13.6 & 436 & 39.7 & 37.5 & 110.4 \\
\hline M3 & $126^{\circ} 13.75^{\prime}$ & $30^{\circ} 27.50^{\prime}$ & 0.37 & . & 1.99 & 12.0 & 490 & 26.5 & 22.5 & 28.7 \\
\hline M4 & $124^{\circ} 16.67^{\prime}$ & $30^{\circ} 4.17^{\prime}$ & & & 1.47 & 9.56 & 368 & 23.3 & 26.1 & 49.5 \\
\hline M5 & $123^{\circ} 4.17^{\prime}$ & $28^{\circ} 16.67^{\prime}$ & 0.31 & 5.75 & 2.42 & 16.8 & 412 & 27.4 & 30.0 & 35.5 \\
\hline M6 & $124^{\circ} 5.84^{\prime}$ & $27^{\circ} 53.33^{\prime}$ & 0.29 & 5.66 & 1.68 & 8.84 & 324 & 20.4 & 26.3 & 52.4 \\
\hline M7 & $122^{\circ} 16.25^{\prime}$ & $27^{\circ} 27.50^{\prime}$ & 0.26 & 4.75 & 2.18 & 10.4 & 369 & 22.4 & 22.5 & 56.3 \\
\hline M8 & $123^{\circ} 48.75^{\prime}$ & $26^{\circ} 52.50^{\prime}$ & 0.10 & 5.35 & 1.97 & 6.45 & 757 & 25.6 & 26.4 & 52.3 \\
\hline M9 & $121^{\circ} 43.96^{\prime}$ & $26^{\circ} 37.09^{\prime}$ & 0.33 & 5.77 & 2.56 & 16.1 & 488 & 27.5 & 26.3 & 75.9 \\
\hline M10 & $120^{\circ} 47.45^{\prime}$ & $25^{\circ} 55.00^{\prime}$ & 0.37 & 5.76 & 1.99 & 11.2 & 417 & 27.5 & 22.5 & 69.9 \\
\hline M11 & $121^{\circ} 29.90^{\prime}$ & $25^{\circ} 40.00^{\prime}$ & 0.30 & 5.65 & 2.25 & 17.7 & 413 & 27.6 & 22.6 & 66.1 \\
\hline O1 & $127^{\circ} 0.01^{\prime}$ & $30^{\circ} 10.00^{\prime}$ & 0.27 & 4.35 & 1.42 & 8.82 & 293 & 19.3 & 26.3 & 44.6 \\
\hline $\mathrm{O} 2$ & $126^{\circ} 20.00^{\prime}$ & $29^{\circ} 17.50^{\prime}$ & 0.16 & 5.24 & 1.32 & 7.43 & 332 & 16.2 & 18.8 & 33.0 \\
\hline O3 & $125^{\circ} 40.00^{\prime}$ & $28^{\circ} 25.00^{\prime}$ & 0.23 & 5.37 & 2.05 & 7.24 & 389 & 19.4 & 18.8 & 42.2 \\
\hline $\mathrm{O} 4$ & $125^{\circ} 7.50^{\prime}$ & $27^{\circ} 30.01^{\prime}$ & 0.14 & 5.15 & 1.80 & 6.40 & 360 & 20.3 & 22.4 & 46.4 \\
\hline O5 & $124^{\circ} 35.00^{\prime}$ & $26^{\circ} 35.00^{\prime}$ & 0.16 & 5.34 & 1.84 & 5.60 & 216 & 14.2 & 15.0 & 37.1 \\
\hline O6 & $123^{\circ} 31.88^{\prime}$ & $25^{\circ} 56.26^{\prime}$ & 0.15 & 4.87 & 0.62 & 4.29 & 152 & 8.17 & 10.0 & 18.2 \\
\hline
\end{tabular}


Table 2. Comparison of trace metals concentrations in surface sediment in the various continental shelves around the world. (Concentration unit is in $\mu \mathrm{g} / \mathrm{g}$, except $\mathrm{Al}$ and $\mathrm{Fe}$ in \%)

\begin{tabular}{|c|c|c|c|c|c|c|c|c|c|}
\hline Location & $\begin{array}{l}\text { Digested } \\
\text { Reagent }\end{array}$ & $\mathrm{Al}$ & $\mathrm{Fe}$ & $\mathrm{Mn}$ & $\mathrm{Cu}$ & $\mathrm{Ni}$ & $\mathrm{Pb}$ & Zn & Reference \\
\hline East China Sea & $\mathrm{HCl} / \mathrm{HNO}_{3} / \mathrm{HF}$ & $\begin{array}{c}4.4-8.5 \\
(5.7)\end{array}$ & $\begin{array}{c}0.62-4.0 \\
(2.1)\end{array}$ & $\begin{array}{c}152-1152 \\
(484)\end{array}$ & $\begin{array}{c}4.3-42 \\
(15)\end{array}$ & $\begin{array}{c}8.2-49 \\
(26)\end{array}$ & $\begin{array}{l}10-49 \\
(27)\end{array}$ & $\begin{array}{c}18-114 \\
(60)\end{array}$ & This study \\
\hline Arabian Gulf & $\mathrm{HCl} / \mathrm{HNO}_{3} / \mathrm{HF}$ & $\begin{array}{c}0.1-3.5 \\
(0.69)\end{array}$ & $\begin{array}{c}0.1-2.5 \\
(0.69)\end{array}$ & $\begin{array}{c}18-415 \\
(165)\end{array}$ & $\begin{array}{l}2-21 \\
(9)\end{array}$ & $\begin{array}{c}2-101 \\
(30)\end{array}$ & ND & $\begin{array}{l}4-58 \\
(22)\end{array}$ & $\begin{array}{c}\text { Basaham \& } \\
\text { El-Sayed, } 1998\end{array}$ \\
\hline $\begin{array}{l}\text { Mediterranean, } \\
\text { Israel coast }\end{array}$ & $\mathrm{HNO}_{3}$ & $2.0-6.4$ & $0.94-5.94$ & $300-900$ & $5.9-28.5$ & ND & $9.9-20.2$ & $22.6-88.6$ & $\begin{array}{l}\text { Goldsmith et al., } \\
2001\end{array}$ \\
\hline Aegean Sea & $\mathrm{HCl} / \mathrm{HNO}_{3} / \mathrm{HF}$ & $\begin{array}{l}2.8-5.3 \\
(4)\end{array}$ & $\begin{array}{c}0.8-2.8 \\
(1.8)\end{array}$ & $\begin{array}{c}171-323 \\
(251)\end{array}$ & $\begin{array}{c}5.3-30.5 \\
(17)\end{array}$ & ND & $\begin{array}{c}20.7-44.2 \\
(34)\end{array}$ & $\begin{array}{c}13-77 \\
(50)\end{array}$ & $\begin{array}{c}\text { Aloupi and } \\
\text { Angelidis, } 2001\end{array}$ \\
\hline $\begin{array}{c}\text { Banc d'Arguin, } \\
\text { Mauritania }\end{array}$ & $\mathrm{HCl} / \mathrm{HNO}_{3} / \mathrm{HF}$ & $1.19-4.66$ & $0.63-2.34$ & & $2-18$ & $5-32$ & $2.8-8.9$ & $19-65$ & $\begin{array}{c}\text { Nolting et al., } \\
1999\end{array}$ \\
\hline $\begin{array}{l}\text { Campeche shelf, } \\
\text { Gulf of Mexico }\end{array}$ & $\mathrm{HCl} / \mathrm{HNO}_{3}$ & ND & $\begin{array}{c}<0.5-7.9 \\
(1.84)\end{array}$ & $\begin{array}{c}12.5-449 \\
(111)\end{array}$ & $\begin{array}{c}3.8-18.7 \\
(7.5)\end{array}$ & $\begin{array}{c}0.56-76.9 \\
(23.0)\end{array}$ & $\begin{array}{c}0.22-20.2 \\
\quad(4.3)\end{array}$ & $\begin{array}{c}0.04-79.6 \\
(18.5)\end{array}$ & $\begin{array}{c}\text { Macias-Zamora } \\
\text { et al., } 1999\end{array}$ \\
\hline $\begin{array}{l}\text { Laptev Sea, } \\
\text { Siberia }\end{array}$ & $\mathrm{HCl} / \mathrm{HNO}_{3} / \mathrm{HF}$ & & $1.9-5.2$ & $187-5398$ & $2-20$ & $16-33$ & $12-22$ & $56-120$ & $\begin{array}{l}\text { Nolting et al., } \\
1996\end{array}$ \\
\hline $\begin{array}{c}\text { Chukchi Sea, } \\
\text { Alaska }\end{array}$ & $\mathrm{HNO}_{3} / \mathrm{HF}$ & $\begin{array}{l}1.6-8.3 \\
(4.7)\end{array}$ & $\begin{array}{l}0.7-8.1 \\
(3)\end{array}$ & $\begin{array}{l}96-610 \\
(252)\end{array}$ & $\begin{array}{l}8-31 \\
(17)\end{array}$ & $\begin{array}{c}10-38 \\
(22)\end{array}$ & ND & $\begin{array}{l}23-106 \\
(61)\end{array}$ & $\begin{array}{l}\text { Naidu et al., } \\
1997\end{array}$ \\
\hline Pechora Sea, Russia & $\mathrm{ND}$ & $\begin{array}{c}2.97-6.88 \\
(4.7)\end{array}$ & $\begin{array}{c}0.51-6.88 \\
\text { (3) }\end{array}$ & $\begin{array}{c}154-684 \\
(377)\end{array}$ & $\begin{array}{l}4-25 \\
(13)\end{array}$ & $\begin{array}{l}6-47 \\
(25)\end{array}$ & $\begin{array}{l}9-22 \\
(14)\end{array}$ & $\begin{array}{l}7-97 \\
(47)\end{array}$ & $\begin{array}{l}\text { Loring et al., } \\
\quad 1995\end{array}$ \\
\hline
\end{tabular}


Table 3. The area, ranges of metals concentration, mass accumulation rate (MAR), and annual sedimentation flux for each box of the East China Sea.

\begin{tabular}{|c|c|c|c|c|c|c|c|c|}
\hline Box & $\begin{array}{c}\text { Area } \\
\left(\mathrm{km}^{2}\right)\end{array}$ & $\operatorname{MAR}^{*}\left(\mathrm{~g} / \mathrm{cm}^{2} / \mathrm{y}\right)$ & $\mathrm{Fe}$ & $\mathrm{Mn}$ & $\mathrm{Cu}$ & $\mathrm{Ni}$ & $\mathrm{Pb}$ & $\mathrm{Zn}$ \\
\hline \multicolumn{9}{|c|}{ metals concentration (Fe in \%; all others in $\mu \mathrm{g} / \mathrm{g}$ ) } \\
\hline I & 31900 & $0.40-1.09(0.75)$ & $1.66-2.00(1.80)$ & $251-593(391)$ & 8.8-32.1 (17.4) & 22.4-39.7(28.2) & 26.3-33.8 (31.3) & $31.8-96.9(60.0)$ \\
\hline II & 98600 & $0.28-1.17(0.73)$ & $1.99-3.97(2.99)$ & $417-1152(869)$ & $11.2-41.5(30.3)$ & $27.5-48.6(37.3)$ & $22.5-44.8(32.9)$ & $69.9-114(94.6)$ \\
\hline III & 53000 & $0.06-0.98(0.32)$ & $1.47-2.19(1.93)$ & $368-436(400)$ & $9.6-13.7$ (10.9) & 19.3-39.8(27.1) & $26.0-37.5(30.8)$ & 33.9-110 (62.0) \\
\hline IV & 86600 & $0.07-0.61(0.26)$ & $0.65-2.56(1.96)$ & $152-757(417)$ & $4.3-17.7$ (11.5) & $8.2-27.6(22.7)$ & $10.0-30.0(23.4)$ & $18.2-75.9(51.0)$ \\
\hline $\mathrm{V}$ & 105800 & $0.03-0.13(0.072)$ & $1.32-2.05$ (1.74) & $216-490(347)$ & $5.6-12.0(7.92)$ & $14.2-26.5(19.3)$ & $15.0-26.2(20.6)$ & $28.7-46.4(38.7)$ \\
\hline \multicolumn{9}{|c|}{ annual metals sedimentation flux $\left(10^{9} \mathrm{~g} / \mathrm{y}\right)$} \\
\hline I & & & $2120-7000(430$ & $32-207(93.6)$ & $1.13-11.2(4.2)$ & $2.9-13.8(6.70)$ & $3.4-11.7(7.5)$ & $4.1-33.7(14.4)$ \\
\hline II & & & $5500-45800(21500)$ & 115-1330(625) & 3.1-47.9 (21.8) & 7.6-56.1(26.9) & $6.2-51.7(23.6)$ & 19.3-131(68.1) \\
\hline III & & & $470-11400(3270)$ & $11.7-227(68.0)$ & $0.3-7.1(1.9)$ & $0.6-20.6(4.60)$ & $0.8-19.5(5.2)$ & $1.1-57.4(10.5)$ \\
\hline IV & & & $(4400)$ & $9.2-400(93.8)$ & $0.3-9.4(2.6)$ & $0.5-14.6(5.1)$ & $0.6-15.8(5.3)$ & $1.1-40.1(11.5)$ \\
\hline $\mathrm{V}$ & & & $390-2800(1320)$ & $6.4-67.0(26.4)$ & $0.2-1.7(0.6)$ & $0.4-3.6(1.5)$ & $0.4-3.6(1.6)$ & $0.9-6.4(2.9)$ \\
\hline Total & & & $8850-80500(34800)$ & 175-2230(907) & $5.0-77.1(31.0)$ & $12.0-109(44.8)$ & $11.5-102(43.2)$ & 26.4-269 (108) \\
\hline
\end{tabular}

Value in parentheses is an average. *: data taken from Huh and Su (1999), Su and Huh (2002) 
Table 4. The annual suspended load, the concentration of riverine particulate metals and annual transportation flux of particulate metals of the major Chinese rivers entering to the East China Sea.

\begin{tabular}{|c|c|c|c|c|c|c|c|c|}
\hline River & $\begin{array}{l}\text { Suspended Load } \\
\qquad\left(10^{6} \mathrm{t} / \mathrm{yr}\right)\end{array}$ & $\mathrm{Fe}$ & $\mathrm{Mn}$ & $\mathrm{Cu}$ & $\mathrm{Ni}$ & $\mathrm{Pb}$ & $\mathrm{Zn}$ & Reference \\
\hline \multicolumn{9}{|c|}{ Riverine particulate metals conc. (Fe in \%; all others in $\mu \mathrm{g} / \mathrm{g}$ ) } \\
\hline Changjiang & 461.4 & 5.2 & 811 & 62.3 & 64.2 & 39.9 & 97.7 & \multirow{5}{*}{ Zhang and Liu, 2002} \\
\hline Qiantangjiang & 4.4 & & & 89.3 & 92.6 & 76 & & \\
\hline Jiaojiang & 8.4 & 3.62 & 878 & 36.5 & 46.1 & 54.8 & 105 & \\
\hline Minjiang & 7.7 & & & 51.8 & & 62.5 & & \\
\hline Jiulongjiang & 3.1 & 5.12 & 1620 & 39.5 & 81 & 60.6 & 228 & \\
\hline \multicolumn{9}{|c|}{ Annual flux $\left(10^{9} \mathrm{~g} / \mathrm{yr}\right)$} \\
\hline Changjiang & & 23993 & 374.20 & 28.75 & 29.62 & 18.41 & 45.08 & \\
\hline Qiantangjiang & & & & 0.39 & 0.41 & 0.33 & & \\
\hline Jiaojiang & & 304.1 & 7.38 & 0.31 & 0.39 & 0.46 & 0.88 & \\
\hline Minjiang & & & & 0.40 & & 0.48 & & \\
\hline Jiulongjiang & & 158.7 & 5.02 & 0.12 & 0.25 & 0.19 & 0.71 & \\
\hline Tot & Flux & 24456 & 386.59 & 29.97 & 30.67 & 19.87 & 46.67 & \\
\hline
\end{tabular}

